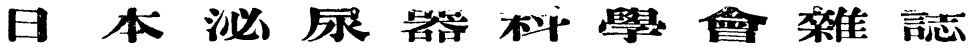 第二十八管 五 知 昭和十四平五月
}

THE JAPANESE JOURNAL OF UROI,OKY Y

VOL. 28, NO 5, MAY. 1939.

原 著

「ヂセプタール」中外 $($ Diseptal $)=ヨ ル$ 男子尿道淋, 治療成績二就于

慶憵義熟大學醫學部皮店科泌尿器科呚空（泌尿器科主:任 北川㸚授）

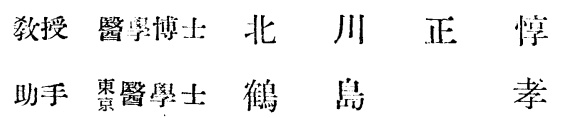

Aus der Dermato-Urologischen Klinik der medizinischen Fakultät der Keio-Gijuku Universität. (Vorstand; Prnf. Ir. M. Kitagawa.

\section{Behandlung mit Diseptal-Chugai bei Urethritis gonorrhoica.}

Von

\author{
Prof. Dr. M. Kitagawa und Dr. T. Turusima.
}

Auf Grund unserer Beobachtungen uber die Urethritis gonorrhoica an 33 Fällen, welche der Behandlung mit "Diseptal-Chugai" ausgesetzt wurden, hat man in unserer Urologischen-Abteilung folgende Resultate erzielt;

Das Präparat "Diseptal-Chugai" ist in Zusammensetzung mit dem Uliron identisch. Es wurden in sämtlichen Fällen eine tägliche Dose von 5.0 g. fortlauf-end, und oral verabreicht.

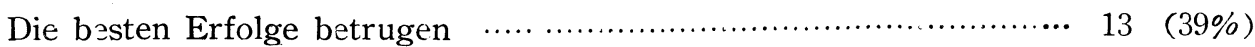

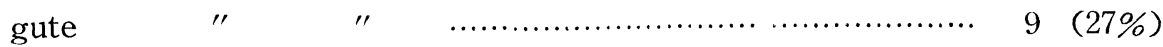

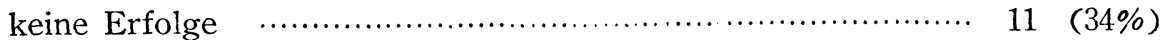

In 20 Fällen von acuter Urethritis ist die sichtliche Wirkung $4(20 \%)$, in 8 subacuten $5(62 \%)$, in 6 chronischen $4(80 \%)$. 
Bei Fällen, die nach 2-3 Wochen seit dem Befallen zur Behandlung kamen ergaben sich gute Wirkungen. 9 (27\%) unter diesen 33 Personen klagten über folgende Nebenerscheinugen: Fiebersteigerung 4, urticarielle Exantheme 3, Frösteln, Schwindel, Appetitmangel und Salzurie.

目

I. 緒 言

I. 症例並治療方法

I. 服用日數

III. 服用總量

V. 治療成績

V. 發病又八再發ヨリ治療開始マデノ日數及
次

\section{治療成績卜ノ關係}

VII. 本刻/大量療法卜作用療法

VII. 副作用二就テ

$\mathrm{X}$, 合作症二就テ

X. 總 括

XI. 絬語

\section{I. 緒言}

1932年 Domagk 並= Mietsch, Klarer 等ノ共同研究ニョツテ, Prontosil ガ創製セラレ

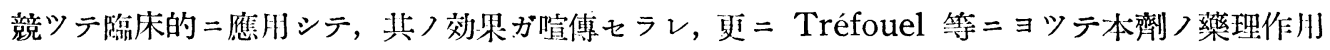
八, Sulfonamid 基=位スル或ガ明トナツテ以來，化學療法二於ケル白仙「プッントジル」 $\mathrm{H}_{2} \mathrm{~N}$ $\mathrm{SO}_{2} \mathrm{NH}_{2}$ 八, 俄二重視セラレ，各國二於テ多數つ同一製㓧ガ作製サレ，臨床的二モ幾多つ發

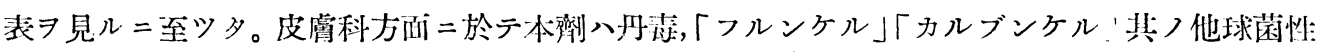
諸疾患二著效习乲スル事八廣ク一般二承認セラレ多數ノ文獻二徴スルモ明デアルガ, 泌尿器科 方面ニ於テモ眢 $=$ Kloss, Renner $=ョ リ$ 尿路球菌性疾患 $=$, Linser, Hanck u. Becker 等 ニョリ淋疾二應用セラレ其ノ效果习認メラレタ。

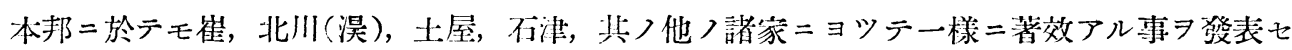

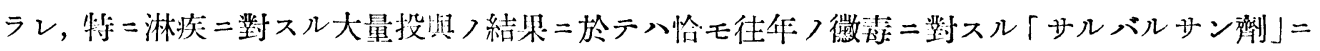
モ比スベキ著效习認メラレ淋疾治療ニ一新紀元习畫シタカノ感ガアツタ。

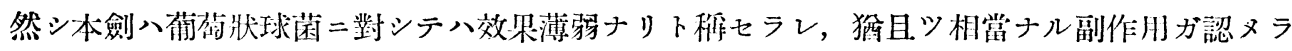
レ，此ノ點二於テ八何等カノ改善ヨ必要トスル事ガ漸次鮮明トナル

1937年 Domagk 等ハSulfonamid 基尹 2侗有スル Diseptal A. B $\sim$ C 製作シ，其ノ 內 $\mathrm{A}$ 郎チ $\mathrm{H}_{2} \mathrm{~N} \square \mathrm{SO}_{2} \mathrm{NH} \square \mathrm{SO}_{2} \mathrm{~N}\left(\mathrm{CH}_{3}\right)_{2}$ 八最モ毒力弱ク人體二使用シ得ベク, 更二動

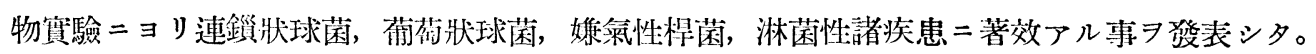
彼ノ「ウリロン」, 本邦二於テハ「ヂセプタール」等ガ之二屬スルモノデアル。

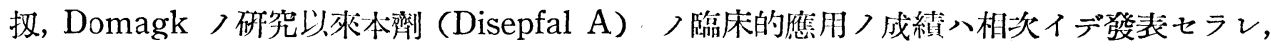
Felke, Scherber u. Domes, Werner, H. Fuhs u. W. Volarsek, Löhe u. R. Wawersig, 等八「ウリロン」 


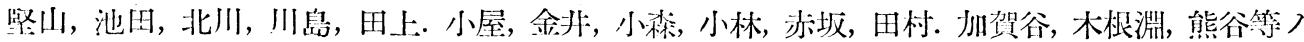
諸氏ニヨリ「ウリロン」或ハ「アルバジル」ニヨル侲秀ナル治驗成樍ガ敒表セラレタ。

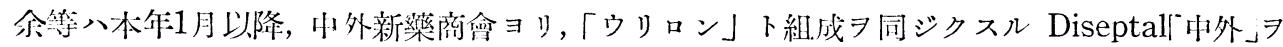

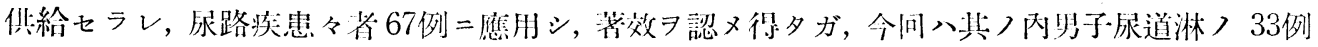
ニ於ケル治洊成績ニ就イテ記載セントスルモノデアル。

\section{II. 症例及治療方法}

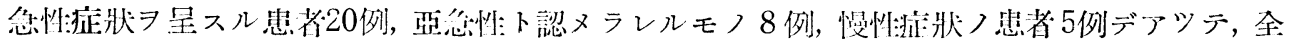

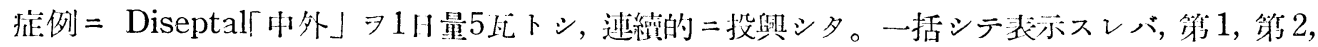

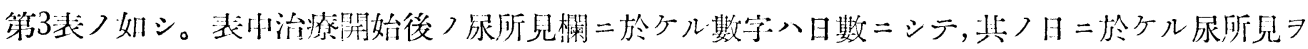
裴スモノデアル。

第 1 表 急性症犾 7 呈スル男子尿道淋

\begin{tabular}{|c|c|c|c|c|c|c|c|c|c|c|c|c|}
\hline \multirow{2}{*}{$\begin{array}{l}\text { 番 } \\
\text { 號 }\end{array}$} & \multirow{2}{*}{ 患者 } & \multirow{2}{*}{ 年㙰 } & \multirow{2}{*}{\begin{tabular}{|l} 
墢病ヨリ \\
治憭開始 \\
マデノ日 \\
數
\end{tabular}} & \multirow{2}{*}{$\begin{array}{c}\text { 初猃 時 } \\
\text { 尿 所 見 } \\
\text { 尿溷|膿球淋菌 }\end{array}$} & \multicolumn{2}{|c|}{$\begin{array}{l}\text { ヂセプタ } \\
\text { ール服用 }\end{array}$} & \multicolumn{3}{|c|}{ 治療開 始 後 } & \multirow{2}{*}{$\begin{array}{ll}\text { 併 } & \text { 川 } \\
\text { 瘏 法 }\end{array}$} & \multirow{2}{*}{ 副 作 用 } & \multirow{2}{*}{ 刵定 } \\
\hline & & & & & $\begin{array}{l}1 \text { 日 } \\
\text { 量 }\end{array}$ & 總量 & & 膿球 & 淋菌 & & & \\
\hline 1 & 桑O & 26 & 15 & $(\mathrm{H})(\mathrm{H})(\mathrm{H})$ & 5 & 5 & $\overline{(\mathrm{H})}$ & $(\mathrm{H})$ & $(+)$ & - & - & 無 效 \\
\hline 2 & 淺○ & 27 & 10 & $(\mathrm{Ht})(\mathrm{HH})(\mathrm{HH})$ & 5 & 15 & $(H)^{2}$ & $(+t) 2$ & $(+) 2$ & - & - & 稍有效 \\
\hline 3 & 件O & 24 & 4 & $(\mathrm{HH})(\mathrm{HH})(\mathrm{H})$ & 5 & 20 & 不明 & $(\mathrm{H}) 2$ & $(t+2)$ & - & - & 無 效 \\
\hline 4 & 村 0 & 23 & 90 & $(\mathrm{H})(\mathrm{Ht})(\mathrm{H})$ & 5 & 20 & 不明 & $(t+)$ & $(-) \overline{9}$ & - & - & 著 效 \\
\hline 5 & 住( & 26 & 17 & $(\mathrm{HH}(\mathrm{HH})(\mathrm{HH}$ & 5 & 20 & $(+) 1$ & $(\mathrm{HH})$ & $(t+1$ & - & 頭㾍, 惡寒 & 秒有效 \\
\hline 6 & 坂 $\mathrm{O}$ & 34 & 7 & $(\mathrm{HH})(\mathrm{HH})(\mathrm{Ht})$ & 5 & 25 & $( \pm) 1$ & $(\mathrm{H})$ & $(+) 1$ & - & 彗 障 碍 & 秒有效 \\
\hline 7 & 本 $\mathrm{O}$ & 23 & 3 & $(\mathrm{H})(\mathrm{Ht})(\mathrm{H})$ & 5 & 40 & $( \pm)^{2}$ & $(\mathrm{H})$ & $(+) 2$ & - & 發熱破将7日目 & 有 效 \\
\hline 8 & 杉0 & 20 & 20 & $(\mathrm{t})(\mathrm{HH})(\mathrm{HH}$ & 5 & 45 & $(-) 5$ & $( \pm) 5$ & $(-) 5$ & - & - & 著 \\
\hline$y$ & 佐O & 32 & 4 & $(\mathrm{Ht})(\mathrm{HH})(\mathrm{HH})$ & 5 & 50 & $(\mathrm{H})$ & ( $\mathrm{HH})$ & $(\mathrm{HH})$ & - & 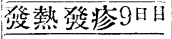 & 無 \\
\hline 10 & 岩O & 31 & 9 & $(\mathrm{H})(\mathrm{HH})(\mathrm{H})$ & 5 & 50 & $(t+)$ & $(\mathrm{HH})$ & $(\mathrm{H})$ & - & - & 無 \\
\hline 11 & 孝( ) & 36 & 15 & $(\mathrm{t})(\mathrm{H})(\mathrm{HI})$ & 5 & bo & $(-) 2$ & $(\mathrm{H}) \overline{2}$ & $(-) 2$ & - & - & 著 效 \\
\hline 12 & 山О & 25 & 3 & $(\mathrm{HH})(\mathrm{Ht})(\mathrm{HH})$ & 5 & 60 & $(+) 2$ & (HI) & $(+) 2$ & - & - & 有 \\
\hline 13 & 松了 & 32 & 5 & $(\mathrm{H})(\mathrm{HI})(\mathrm{HH})$ & 5 & 65 & $(+)$ & (H) & $(H)$ & - & - & 無 \\
\hline 14 & 鈴 0 & 36 & 2 & $(\mathrm{HH})(\mathrm{Ht})(\mathrm{HH})$ & 5 & 70 & $(\mathrm{H}) 2$ & $(\mathrm{Ht}) 2$ & $(+) 2$ & 5日目 ${ }^{\exists}$ 沙滌 & - & 無 \\
\hline 15 & 當O & 25 & 2 & $(\mathrm{Ht})(\mathrm{Ht}) \overline{(\mathrm{Ht})}$ & 5 & 70 & $(\mathrm{H})$ & $(\mathrm{Ht})$ & $(H)$ & - & - & 無 \\
\hline 16 & 片O & 21 & 14 & $(\mathrm{HI})(\mathrm{H})(\mathrm{Ht})$ & 5 & 70 & $(-) 1$ & $(H) 1$ & $(-) 1$ & - & - & 薯 \\
\hline 17 & 鈴O & 35 & 40 & $(\mathrm{t})(\mathrm{HI})(\mathrm{HH})$ & 5 & 75 & $(+)$ & $(\mathrm{HH})$ & $(+) 4$ & 2日目ヨリ洗滌 & 頭痛食㱃不振 & 無 \\
\hline 18 & 望O & 45 & 5 & $(\mathrm{Ht})(\mathrm{HH})(\mathrm{HH})$ & 5 & 115 & $(-)^{2}$ & $(t+2$ & $( \pm)^{2}$ & - & 倳 & 有 \\
\hline 19 & $\equiv \mathrm{O}$ & 28 & 7 & $(+)(H)(H)$ & 5 & 115 & $( \pm)_{3}^{3}$ & $(\mathrm{H}) \overline{3}$ & $(+) 3$ & - & - & 有 \\
\hline 20 & 世O & 23 & 17 & $(\mathrm{HH})(\mathrm{HH})(\mathrm{HH})$ & 5 & 235 & $(\mathrm{HH})$ & $(\mathrm{HH})$ & $(t+3$ & 39日 Пヨリ洗滌 & - & 無 效 \\
\hline
\end{tabular}

第 2 表 亞急性症彇

\begin{tabular}{|c|c|c|c|c|c|c|c|c|c|c|c|c|c|c|}
\hline \multirow{2}{*}{$\begin{array}{l}\text { 番 } \\
\text { 號 }\end{array}$} & \multirow{2}{*}{ 患者 } & \multirow{2}{*}{ 年齡 } & \multirow{2}{*}{\begin{tabular}{|l} 
登病ヨリ \\
治療開始 \\
マデノ日 \\
數
\end{tabular}} & \multicolumn{3}{|c|}{ 初診時尿所兄 } & \multicolumn{2}{|c|}{$\begin{array}{l}\text { ジセプタ } \\
\text { ール服用 }\end{array}$} & \multicolumn{3}{|c|}{ 治療䦭 始 後 } & \multirow{2}{*}{$\begin{array}{ll}\text { 併 用 } \\
\text { 療 法 }\end{array}$} & \multirow{2}{*}{ 副 作 用 } & \multirow{2}{*}{ 制定 } \\
\hline & & & & 溷濁 & 膿球 & 淋菌 & $\begin{array}{l}\text { 1日 } \\
\text { 量 }\end{array}$ & 總量 & 蜀 & 膿球 & 淋菌 & & & \\
\hline 1 & 兵 $\mathrm{O}$ & 42 & 90 & $(+)$ & $\mathrm{HH}$ & + & 5 & 15 & $\overline{( \pm) 1}$ & $(\mathrm{Ht})$ & $(+) 1$ & - & - & 住 \\
\hline 2 & 渄O & 29 & 19 & $(t)$ & $(\mathrm{HH})$ & $(\mathrm{Ht})$ & 5 & 25 & 不时 & $(\mathrm{HH})$ & $(\mathrm{HH})$ & 洗 滌 2 回 & - & 無 \\
\hline 3 & 部○ & 22 & 35 & $(\mathrm{Ht})$ & $(\mathrm{HH})$ & $(\mathrm{HH}$ & 5 & 40 & $(+) 3$ & $(H)$ & $(-) 14$ & - & - & 著 \\
\hline 4 & 營0 & 51 & 52 & $(+)$ & $(\mathrm{HH})$ & $(\mathrm{HH})$ & 5 & 40 & $( \pm) ?$ & $(\mathrm{HH})$ & $(\mathrm{Ht})$ & 一 & - & 無 \\
\hline 5 & 早0 & 33 & 18 & $(+)$ & $(\mathrm{HH})$ & $(\mathrm{H})$ & 5 & 45 & $(-)$ & $(\mathrm{H}) 2$ & $(-)^{2}$ & - & 二 & 湿 \\
\hline 6 & 柳O & 59 & 18 & (H. & $\mathrm{CH}$ & $(\mathrm{HH})$ & 5 & 80 & 不时 & $(H) 1$ & $(-) 1$ & - & 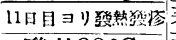 & 效 \\
\hline 7 & 武O & 30 & 20 & $(+t)$ & $(\mathrm{HH})$ & $(\mathrm{H})$ & 5 & 60 & $(-) 1$ & $(+) 1$ & $(-) 1$ & - & 發熱 $38^{\circ} \mathrm{C}$ & 效 \\
\hline 8 & 五只 & 30 & 46 & $\overline{(+)}$ & $(\mathrm{H})$ & $(\mathrm{HI})$ & 5 & 90 & $(-) 2$ & $( \pm) 2$ & $(-) 2$ & - & 監 類 尿 & 著 \\
\hline
\end{tabular}


第 3 表 慢性症狀 $习$ 呈スル男子尿逆淋

\begin{tabular}{|c|c|c|c|c|c|c|c|c|c|c|c|c|c|c|}
\hline \multirow{2}{*}{$\begin{array}{l}\text { 番 } \\
\text { 號 }\end{array}$} & \multirow{2}{*}{ 患者 } & \multirow{2}{*}{ 少: } & \multirow{2}{*}{ 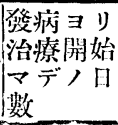 } & \multirow{2}{*}{$\frac{\text { 初診時㽷所見 }}{\text { 溷䍖膿球淋菌 }}$} & \multicolumn{2}{|c|}{$\begin{array}{l}\text { ヂヤプタ } \\
\text { ール服同 }\end{array}$} & \multicolumn{3}{|c|}{ 治療開始後 } & \multirow{2}{*}{$\begin{array}{l}\text { 作 } \\
\text { 療 }\end{array}$} & \multirow{2}{*}{\multicolumn{2}{|c|}{$\begin{array}{l}\text { 用 } \\
\text { 法 } \\
\end{array}$}} & \multirow{2}{*}{ 副 作 用 } & \multirow{2}{*}{ 籼定 } \\
\hline & & & & & $\begin{array}{l}1 \text { 日 } \\
\text { 量 } \\
\end{array}$ & 總量 & 㽷淍濁 & 膿球 & 淋菌 & & & & & \\
\hline 1 & 波0 & 40 & 360 & $(-)(\mathrm{Ht})(+)$ & 5 & 30 & $(-)^{2}$ & $( \pm)^{2}$ & $(-) 2$ & & $=$ & & - & 篧 \\
\hline 2 & 小O & 30 & 105 & $( \pm)(\mathrm{Ht})(\mathrm{HH})$ & 5 & 55 & $(-) 3$ & $(+) 3$ & $(-) 3$ & & - & & - & 著 \\
\hline 3 & 阿 $\mathrm{O}$ & 35 & 120 & $\pm)(\mathrm{Ht})(\mathrm{HI})$ & 5 & 60 & $(-) 6$ & $(t+)^{13}$ & $(-)^{13}$ & & - & & 7 & 著 \\
\hline 4 & 丸O & 29 & 300 & $(-)(\mathrm{HH})(\mathrm{H})$ & 5 & 75 & $(-)$ & $( \pm) 1$ & $(-) 1$ & & - & & - & 等 \\
\hline 5 & is 0 & 29 & 90 & $(t)(\mathrm{H})(\mathrm{Ht})$ & 5 & 85 & $(-) 5$ & $H$ & ( \pm 11 & $3 \llbracket 1$ & 日”y & 沉滌 & - & 有 \\
\hline
\end{tabular}

\section{II. 服用 日 數}

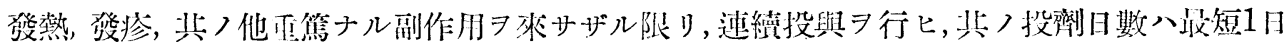

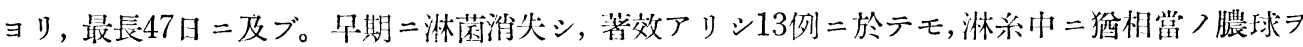
含么場合二八繼續投與シ夕。

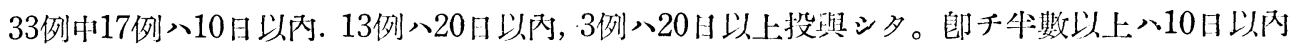
ノ投與デアル。

\section{雨. 服用總 量}

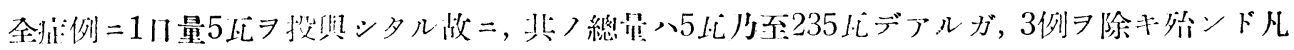

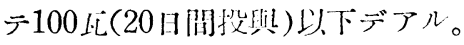

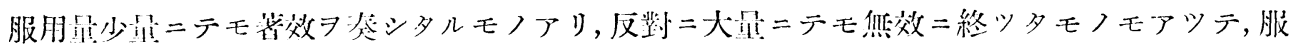

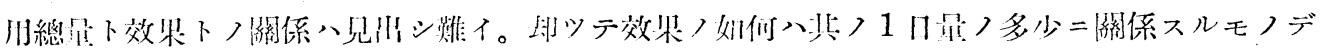
アルト思惟スル。

\section{V. 治 療 成 績}

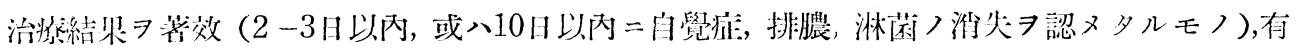

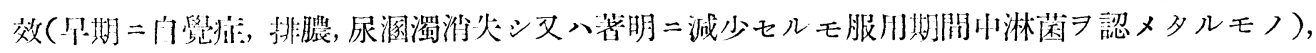

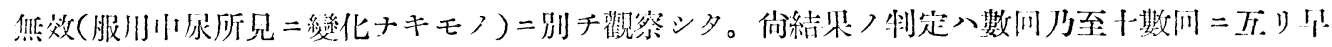

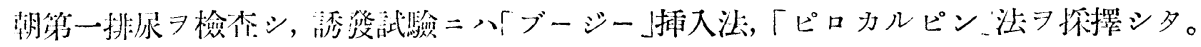

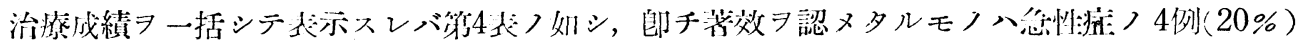

第 4 表 治源成績

\begin{tabular}{|c|c|c|c|c|}
\hline & 著 效 & 存 效 & 㶵 效 & it \\
\hline 急 性 & $4(20 \%)$ & $7(35 \%)$ & $945 \%)$ & 20 \\
\hline 亞急性 & $5(62.5 \%)$ & $1(12.5 \%)$ & $2(25 \%)$ & 8 \\
\hline 慢 性 & $4(80 \%)$ & $1(20 \%)$ & 0 & 5 \\
\hline it & $13(39 \%)$ & $9.27 \%)$ & $11(34 \%)$ & 33 \\
\hline
\end{tabular}

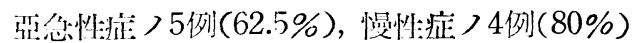
デアル。惩效ナリシモノ八柋性淋二於テ9例 (45\%), 亞急性淋二テハ2例 (25\%), 慢性淋 ニ於テハ零デアル。汒ヨ有效率ヨリ觀祭ス

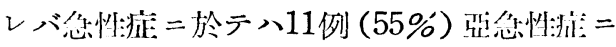
テ八6例 (75\%), 慢性疪二於テハ5例 $(100 \%)$ デアツテ留急性仯至慢性的倾向アル症例程， 


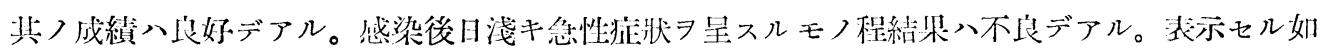

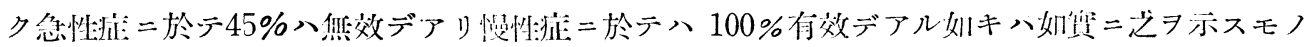
デアル。以上)結坚习諸家 (H. Fuhs u. W. Volarsek, Loos, 土屋, 俈藤, 北川, 石津, 北川,

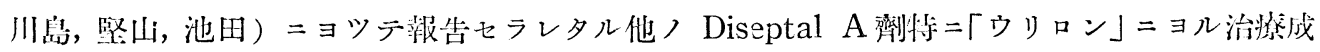
縝卜此較スル二略同椂ノ成績ナルコトラ認又得夕。

\section{II. 發病又八再發ヨリ治療開始マデノ日數及治療成績卜ノ關係}

柋性症快 以內ノモノ3例，3週以內ノモノ5例，4週以上ノモノ2例デアル。

亞急性症狀习旺スルモノデハ最短18日ヨリ最長90日デアルガ, 2 週以上 3 週以內ノモノ4例,4週 以上5週以內ノモノ 1 例。5週以上經佣七ルモノ3例デアル。

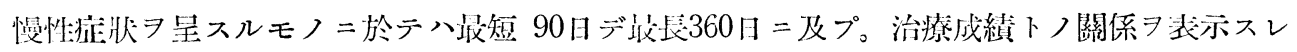
バ第5㸞つ如シ。

郎于發病後 1 洬以內二於デ 燎法 7 開始七几10例=於テ八有 效5(50\%)哭效5(50\%)デ 2週以 內ノモノ3例デ 八者效, 有效, 無 效, 各1例(33\%), 3週以內 9 例 デ 八著效 $5(62.5 \%)$ 有效 $1(13 \%)$ 舆效 $3(24.5 \%)$ デアル。4週以後 ノ11例デ八著效7 (64\%), 有效, 鮥 效各 $2(18 \%)$ デ碚疮後日數 7 經 ルニ順ツテ好成續ノモノ多ク，

第 5 表 被狱ヨリ治潦開始マデ，期间 卜治療戌綪卜ノ關係

\begin{tabular}{|c|c|c|c|c|c|}
\hline & 1週以內 & 2週以內 & 3 週以内 & 4週以上 & it \\
\hline 总 性 & 10 & 3 & 5 & 2 & 10 \\
\hline 亚急性 & & & 4 & 4 & 8 \\
\hline 慢 性 & & & & 5 & 5 \\
\hline 郭 & 10 & 3 & 9 & 11 & 33 \\
\hline 著 效 & 0 & $1(33 \%)$ & $5(62.5 \%)$ & $7(64 \%)$ & $13(39 \%)$ \\
\hline 存 效 & $5(50 \%)$ & $1(33 \%)$ & $1(13 \%)$ & $2(18 \%)$ & $\mathrm{e}(27 \%)$ \\
\hline 無 效 & $5(50 \%)$ & $1(33 \%)$ & $3(24.5 \%)$ & $2(18 \%)$ & $11(34 \%)$ \\
\hline
\end{tabular}

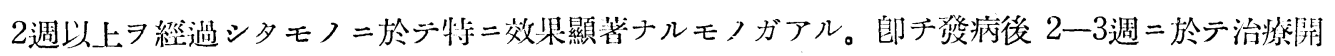
始セルモノノ有效率入 $75,5 \%, 4$ 週以後ノモノデハ $82 \%=$ 及ンデキル。斯ノ如キ結果八多数つ學 者 (Grütz, Felke, Schreus, Fischer, Loos, Scherber, Schubert, Wagner u. Pohlner,

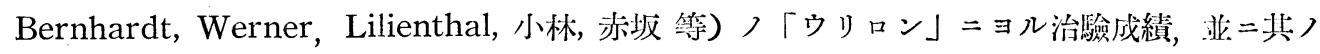

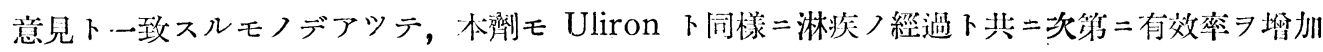
スルモノト思ハレ，「ウリロン」ノ有效，哭效八適應氿定ノ如何＝關係シ感染後 5一6週以上习

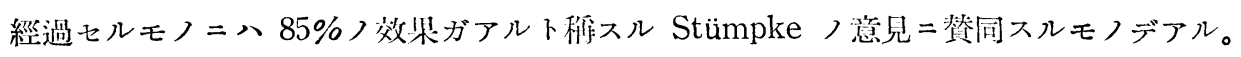

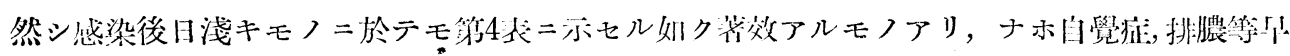

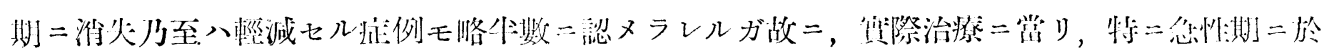

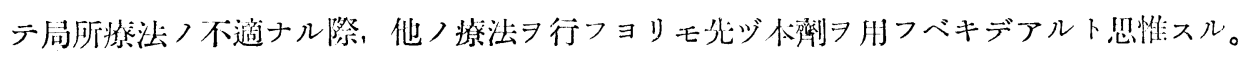




\section{VII. 本劑ノ大量療法卜併用法}

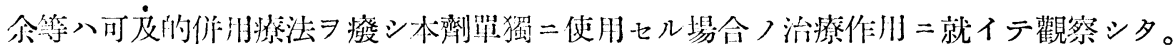

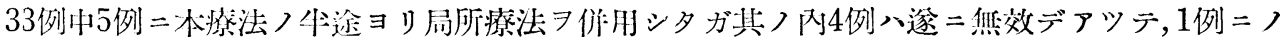
ミ局所的作用療㳂ノ效具习認メ得夕。

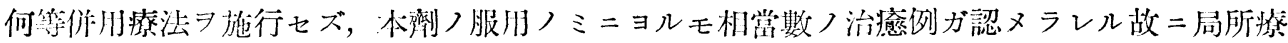

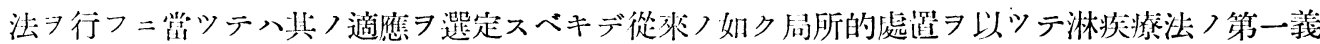
トスル觀仝ハ毁二今日二於テハ改メラルベキデアルト思惟スル。

\section{VIII. 副 作 用 二 就 テ}

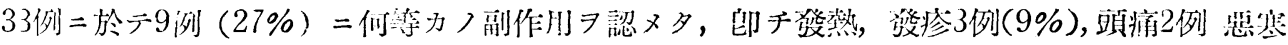

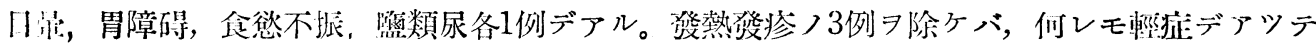

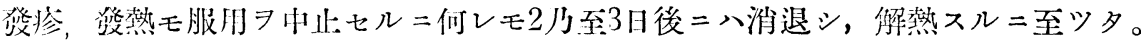

「ウリロン」ノ治驗報告ニ於テ Dölken ハ370例中47例ノ中表症例中特二视枊經炎ラ 雷要视

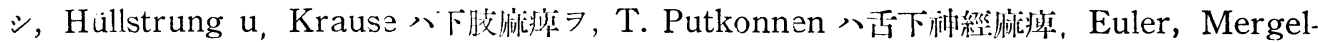

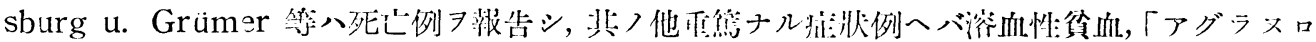

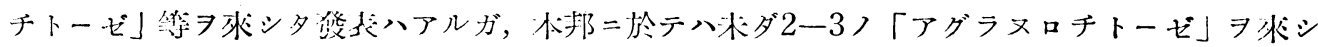

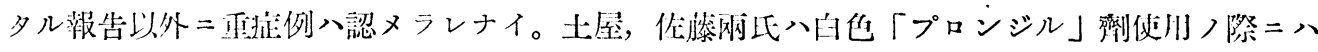

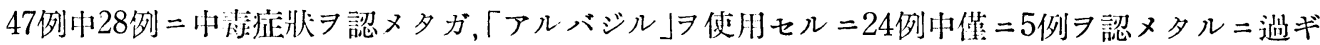
ズ，何レモ签症デアツテ，白仰「プロントジル㧕ニ比シ胃障碍ノ僅微ナル點八內服二好適ナル 事习指摘シタ。余等モ亦第28回泌尿器科學會總會二於テ,白色「プロントジル」劑下 Diseptal 「中外」トノ副作脂 7 比较報告シタガ前者二於テハ 95 例中 49 例 (58\%) =種くナル副作用习認メ ラレ，其ノ內比較的重症デアツタ䓈熱，發疹13例 $(15 \%)=$ 比スレバ Diseptal「中外」二於ヶ ル副作脳發生率ハ遙ニ少數デアツテ此ノ點ヨリ觀祭スルモ迌二大量療法ニ適スルモノデアルト 考へル。

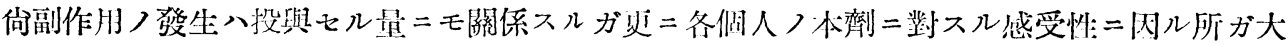

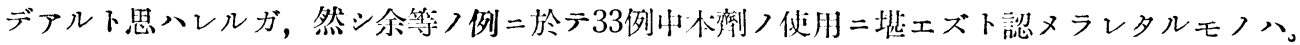

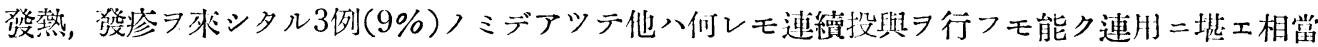
フ效果フ舉ゲティル。患者つ全身狀態二留意シッッ，世間二廣ク行ハレル如ク衝撃的二投與ス

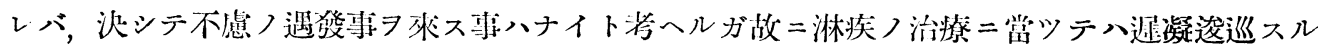
事価ク林劑习大量二投與スベキデアルト思惟スル。

\section{IX. 合 併 症 二 就 テ.}

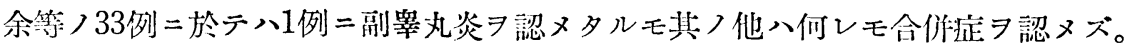

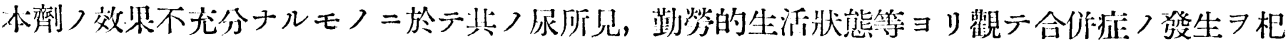


眐シタルモノニ於テモ木劑服䏳中ハ遂ニ之ヨ見ナカッタ事八興味アル處デアツテ可及的局所療 法ヨ行ハナカツ夕點モ一因ト考へラレルガ，木劑ガ合作症豫防劑トシテモ亦或程度ノ意義ガア ルト思考セラレタ。

\section{$X$ 總括}

1. 33例ノ淋疾患者＝中外新樂商會製 Diseptal[中外」1日量 5 瓦 7 特二連續投䏳シ其ノ治療成 績ヨ觀察シタ。

2. 本劑ハ淋疾つ各期二有效ナルモ，特二發病後 2 週間以上ヨ經過シタルモノ=良好デ陳鹤ナ 儿拉:例程多數例二著效

3. 併肞療法, 特二局所療法入其ノ適應习郔定シ，第二義的療法トシテ行フベキモノト思惟ス ル。

4. 本劑 $=ヨ ル$ 重篤ナル副作用例ニ八遭遇セズ，他ノ白色「プロントジル」劑二比シ副作用八 僅少デアル。

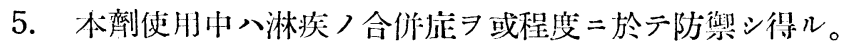

XI 結論

本劑八尿路菌性疾患，特二淋疾二對シ「ウリロン」等下略同樣ノ效ノヨ有シ，本劑 $=ヨ ル$ 療

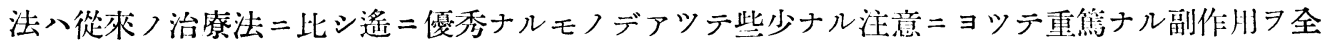
ク防避シ得ルモノデアルカラ徒二本劑ノ使朋ヨ逡巡スル事ナク大量二使用シテ可ナルベキモノ デアルト考へル。

交献

1) Bernhardt : Dermat. Wschr. Bd. 107, Nr. 29. 1938. 2) Domagk : Deut. Med. Wschr. 61, S. 250, 1935. 3) Domagk : Dermat. Wschr, Bd. 107, Nr. 27, 1938. 4) Dölken : Dermat. Wschr, Bd 107, Nr. 44, 1938, 5) Felke : Deut. med. Wschr, Nr. 37, $1937 . \quad 6)$ H. Fuhs u. W. Volarsek : Dermat. Wschr. Bd. 107, Nr. 36, $1938 . \quad 7)$ Hüllstrung u. Krause : Deut, med. Wschr. Nr. 4, $1938 . \quad 8)$ Klose : Deut. med. Wschr. Nr. 22,1936. 9) Loos: Dermat. Wschr, Nr. 41, $1938 . \quad$ 10) Löhe u. R. Wawersig : Dermat. Wschr. Bd. 107, Nr. 37, 1938. 11) Samuel, B. : J. Americ. med. assoz. 1938, 110, 368. 12) Renner: Therap. Gegenw. 1936, H. 10, S. 443. 13) Scherber: Wiener. med. Wschr. Nr. 11, 13, 14, u. 18, 1935. 14) Schabert : Dermat. Wschr, B1. 107, Nr $47 . \quad 15)$ Tréfouél : Compt. rend. Soc. de Biol. 1935, 120, 756. 16) Wag -e: u. Pohling : Darmat. Wschr. Bd. 107, Nr. 27, 1938. 17) Werner Lilienthal : Dermat. Wschr. B1. 107, Nr.23, 1938. 18) 石津 俊：治燎及處方, 10替, 224號, 112頁, 昭和13

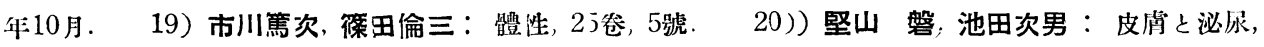
第6卷，第3號，666頁. 昭和13年12月. 2l）加賀谷順次郎，木根淵善吉，熊谷富義： 北越䈣會誌，

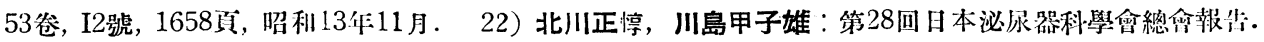
23) 北川 淏：醫界艮望. 193號. 24) 小室秀一郎, 金井 弘, 小森 勇, 床井 恒：束京醫誌, 
3099號。昭和13年9月. 25) 小林 豊, 赤坂 裕： 體性, 25卷, 7號, 42頁. 昭和13年7月. 26)

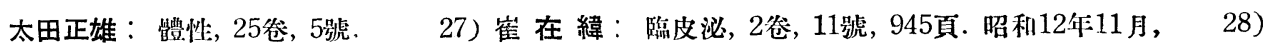

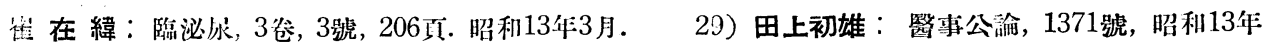
10月，30）田上初雄：醫事公諭，1372號，昭和13年11月。 31）田村 一：臨床の日本, 6尞,

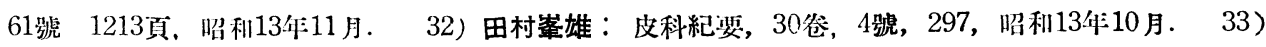
土屋交雄：佐藤正市 體性，25焱，10號，25页，昭和13年10月，34）土屋交雄，佐藤正市： 篟皮泌 3叁 12號，1015页，昭和13年12月. 